\title{
OVERVÅGNINGENS KUNST OVERVÅGNINGSDYSTOPIER OG INTERFACEBEGÆER I DET URBANE RUM I 1984, FACELESS OG ANDRE URBANE INTERFACES
}

"Teleskcermen fungerede samtidig som sender og modtager. Den opfangede enhver lyd, der var bøjere end en ganske sagte bvisken, og så lange han opholdt sig inden for skcermens synsfelt, kunne han ogsa ses. Det var naturligvis umuligt at vide, om man blev iagttaget. Alle teorier om, bvor tit og efter bvilket system Tankepolitiet gik ind på den enkelte ledning, var og blev det rene gatteri. Det var endda muligt, at de iagttog alle bele tiden, i bvert fald kunne de ga ind på ens ledning når som belst. Man måtte leve i formodningen om, at bvert ord blev aflyttet og enhver bevagelse, undtagen i morke, iagttaget; og man gjorde det, det var en vane, der efterhainden var blevet til instinkt. Winston stod med ryggen til teleskcrmen, det var sikrere, skønt selv en ryg kan vare udtryksfuld, bvad han udmarket godt vidste."

(ORWELL 6)

I mange år havde overvågning en negativ klang i samfundsdebatten, og man behøvede blot at trække George Orwells 1984 frem for at pege på overvågningens negative konsekvenser $\mathrm{i}$ form af et disciplinerende kontrolsamfund uden frihed. De seneste år har overvågning imidlertid fået en renæssance, kameraerne monteres med ny hast, politiet gives nye beføjelser, og politikerne vedtager love, der pålægger teleudbyderne at logge vores færden. Alt sammen kun akkompagneret af spage protester og kritiske spørgsmål til den dokumenterede effekt, mens den brede befolkning har travlt med relativt ubekymret, frivilligt og ufrivilligt, at lægge flere data om os selv ud i nettets kommercielle tjenester. ${ }^{1}$ I denne artikel vil jeg belyse, hvad det er for et kulturelt skift, der foregår omkring overvågning. Udgangspunktet er en undren over den aktuelle udbredelse af overvågning, og hvorfor den spreder sig på trods af velkendte advarsler og udbredt kritik. For at forstå overvågningens aktuelle betydning vil jeg have fokus på koblingen mellem overvågning og computerens interface, hvor overvågningen er en integreret del af funktionaliteten i det kybernetiske feedback-kredsløb, og særligt kigge på kunstprojekter, som diskuterer

1 I skrivende stund f.eks. denne helt aktuelle nyhed fra Århus: Maja Nielsen: "Overvågning fælder ingen kriminelle - Videoovervågningen ved cafemiljøet i city er endnu ikke brugt til opklaring af kriminalitet”, Aarbus Stiftstidende, 2. august 2010, 〈http://stiften.dk/article/20100802/aas/708029972/> (besøgt 02.08.2010). 
overvågningen i det urbane rum. Fra et indledende udgangspunkt i George Orwells roman, 1984, som ovenstående citat stammer fra, vil jeg kigge på, hvordan romanen også indgår i interfacets kulturhistorie via lanceringen af Apples Macintosh. Derefter vil jeg kigge på urban overvågningskunst, bl.a. Manu Luksch’ film Faceless, som herhjemme blev vist på Aros udstillingen Enter Action (Dinesen). ${ }^{2}$

George Orwells 1984 er en klassiker inden for diskussioner af overvågning. Den er berømt for at skildre et samfund, hvor overvågningen er rygraden i et totalitært samfund, hvor grundmekanismen er overvågningens disciplinering af individerne, som beskrevet i citatet fra romanens begyndelse. Denne disciplinering er med andre ord en form for sansemæssig bevidsthed, en bevidsthed om sansning og sansningens funktionalitet og medialitet. Der er nemlig, som vi kan se af citatet, også medieteknologi involveret i form af den overvågende teleskærm. Ofte, ikke mindst i moderne tid, er medieteknologi og teknologiske arkitekturer integreret i overvågningens sansemæssige kerne. Teknologien forstærker og forlænger Benthams panoptikon ${ }^{3}$ i kraft af sin transmission af det sansede og den dermed opnåede adskillelse af den overvågende og den overvågede.

Relationen mellem overvågning og æstetik er langtfra ny. Benthams berømte panoptikon er for eksempel blot et omvendt panorama. Panoramaet var et populært kulturindustrielt massemedie i 1800-tallet sammenligneligt med det tyvende århundredes filmindustri og med gennemslagskraft $i$ alle datidens toneangivende storbyer. Arkitekturen og blikvinklerne er stort set identiske både i den disciplinerende overvågningsarkitektur, panoptikonet, og i det kulturindustrielle visuelle medium, panoramaet. Imidlertid har fangerne i panoptikonet byttet plads med billedet i panoramaet og fangevogterne med publikum. Som Stephan Oettermann præcist udtrykker det: "Panorama og panoptikon er som skoler for blikket både identiske og modsætninger på samme tid. I panoramaet lærer man det blik, gennem hvilket man i panoptikonet bliver belært."4

2 Ud over på Aros blev overvågning tematiseret af udstillingen "No Place to Hide” på Skive Kunstmuseum (2009 - katalog under udgivelse). I forbindelse med sidstnævnte og Aros’ Enter Action (Aros, Aarhus Kunstmuseum, 2009) arrangerede Digital Urban Living og Digital Aesthetics Research Center konferencen Sousveillance. The Art of Inverse Surveillance (Aarhus, 8-9 februar, 2009), hvor en række kunstnere og teoretikere diskuterede kunstneriske strategier i forhold til den tiltagende overvågning (heriblandt Manu Luksch, Jacob Jacobsen, Alexei Shulgin, Dmitry Kleiner, David Rokeby, overvågningsaktivisterne i Space Hijackers og Leipziger Kamera samt den feministiske overvågningskunstner Mare Tralla (cf.: <http://www.digitalurbanliving.dk/sousveillance/> (besøgt 02.08.2010) og 〈http://darc.imv.au.dk/?tag=sousveillance-the-art-of-inverse-surveillance> (besøgt 02.08.2010))). Denne artikel er udarbejdet på baggrund af indlæg på denne konference og på en workshop afholdt af Forum for Overvågningsstudier i marts 2008 (<http://fos.au.dk/〉 (besøgt 02.08.2010)).

3 Som beskrevet i Foucaults indflydelsesrige bog om Bentham. Michel Foucault, Overvågning Og Straf Fangslets Fødsel, trans. på dansk ved Mogens Chrom Jacobsen indledning ved Anders Fogh Jensen, Tidsel-Serien, 2. opl. ed. (Frederiksberg: Det lille Forlag, 2003).

4 "Panorama und Panopticon sind als Schulen des Blicks identisch und gegensätzlich zugleich. Im Panorama wird der Blick gelernt, durch den im Panopticon gelehrt wird." (Oettermann 36, cf. Pold Ex libris medierealistisk litteratur, Paris, Los Angeles \& cyberspace). 
Det betyder selvfølgelig ikke, at kunst og overvågning er det samme. De to områder er imidlertid beslægtede i kraft af deres sansemæssige mediearkitektur - som to sider af den samme samfundsudvikling, der, som også Oettermann gør rede for, handler om, hvordan det moderne massesamfund organiseres, kontrolleres, styres og opleves. I forlængelse af denne sammen- og modstilling mellem overvågningsteknologi og æstetik kan man argumentere for, at kunsten giver os en mulighed for at erkende overvågningens blik. Men kunsten er mere end en tør kritisk dekonstruktion. Den peger også på den lokkende skønhed i overvågningsblikket - drømmen om overblikket, der ser alt. Den peger på voyeurismen, på begæret efter at indtage det omnipotente perspektiv og endda på ekshibitionismen, på begæret efter at blive set og udstillet af det altseende blik. Kunsten peger også på skønheden i abstraktionerne og generaliseringerne; vores virkelighed set fra et altseende synspunkt, hvor vi reduceres til mønstre og spor i sociale konstellationer. Måske endda på skønheden i erkendelsen af overvågningsblikkets blinde vinkler og det liv, der udfoldes i dem? Denne tillokkelse, dette begær, som langt fra udelukkende er instrumentelt, men også kulturelt og æstetisk, skal medtænkes i en forståelse og kritik af overvågning, hvis den ikke skal fejle sit mål.

Uden om overvågningens kerne af sansning ligger der lag af teknologiforståelse, politik og jura, men centralt er altså sansningen og bevidstheden om den, som imidlertid først for alvor konkretiseres for os, når den tematiseres og demonstreres æstetisk i kunst og litteratur som i Orwells roman. 1984 er både teoretisk og i den brede offentlighed blevet kanoniseret som en skarp advarsel mod overvågningens samfundsmæssige konsekvenser, og romanens betydning kan næppe overvurderes. Den er blevet citeret og bearbejdet i adskillige film, tv-serier og i populærkulturen. Ved at følge romanens kulturelle spor - hvordan den er blevet citeret og bearbejdet - ser vi en hel overvågningskultur udfolde sig, som dels gentager romanens dystopiske advarsler, dels reformulerer dens kritik og korrigerer den i forhold til nye sammenhænge.

\section{Interfacet og overvågningens cestetik}

En af de mere overraskende bearbejdninger er i Ridley Scotts berømte reklamefilm for den forste Apple Macintosh, der blev vist under tv-transmissionen af Super Bowl d. 22. januar 1984. En blond, atletisk, kvindelig hammerkaster løber ind i en hal, hvor grå, køns- og udtryksløse mennesker marcherer i takt foran en stor skærm. Hun er jagtet af tankepolitiet, men når lige at kaste sin hammer, der smadrer skærmen i det øjeblik, Store Broder udtaler, "vi vil sejre". Derefter tager en betryggende mandestemme over og læser det budskab, som også fylder skærmen: "Den 24. januar vil Apple Computer introducere Macintosh. Så vil du forstå, hvorfor 1984 ikke vil blive som 1984." (〈http://www.apple-history.com/movies/1984.mov〉, Friedman). Den gamle Big Brother afløses altså af en betryggende onkel, der med en maskulin fortællerstemme forsikrer os om, at 1984 er aflyst og afløst af noget ganske andet, hvis vi blot køber den nye Macintosh, samtidig med, at fjendebilledet (IBM?) bringes i erindring. 
Macintoshens introduktion i 1984 markerede det kommercielle gennembrud for den personlige interaktive computer med et grafisk bruger-interface. Grundlæggende fungerer den interaktive computer via et kybernetisk feedback-kredsløb, hvor brugeren kan påvirke computerens processer i realtid, og computeren aflæser disse påvirkninger og reagerer på dem. Brugeren kan aflæse computeren via dens output gennem f.eks. skærm, højtaler eller print, men computeren kan også aflæse (og dermed overvåge) brugeren via det input, den får via tastatur, mus, mikrofon, kamera eller sensorer. Hvor 1984s 'teleskærm' blot var en transmissionsskærm koblet med et overvågningskamera og mikrofon, er der nu introduceret en computer i kredsløbet, som kybernetisk aflæser og reagerer på brugeren og er koblet op i verdensomspændende netværk.

Men samtidig med den nye teknologi introduceres en ny kultur, som vil frigøre os fra den gamle autoritære overvågningskultur. Den gamle overvågningskultur og computerforståelse, hvor computeren har været associeret med centraliserede kontrolsystemer betjent af grå mænd i hvide kitler, nyfortolkes i retning af et ungdommeligt univers, hvor computeren giver mulighed for selvudfoldelse og måske endda hippe modkulturelle strømninger. Det lykkes altså Apple og andre dele af den californiske computer-industri og forskningsverden at nyfortolke dette overvågningskredsløb som en frigørende revolution i stedet for den undertrykkende dystopi, som er illustreret i reklamefilmen. Computeren blev genfortolket som en frigørende teknologi fjernt fra den kontroltænkning og de militære laboratorier, inden for hvilke, den blev udviklet i 1940'erne og 1950'erne. ${ }^{5}$

Vi har altså at gøre med en mønt med to sider: På den ene side computerens kulturelle og udtryksmæssige muligheder, bl.a. i en frigørelsesdiskurs. På den anden side følger overvågning og den dertil hørende disciplinering nødvendigvis med. Bagsiden af interaktivitet er således overvågning - en pointe, som ofte synliggøres i computerspil (hvor spillenes grundstemning ofte er paranoia), men som understreges yderligere med WWW og de mange spor, vi mere eller mindre frivilligt efterlader til internettjenester som Google og hinanden. Denne form for overvågning er en grundbetingelse for det interaktive interface: Jo bedre interfacet kan aflæse dig, jo bedre kan det også tilpasse sig dig og dermed 'hjælpe' dig. Amazon.com bliver bedre og bedre til at anbefale dig bøger, jo bedre det kender dig, Google rammer dig mere præcist med søgeresultater (og reklamer), og du finder dine venner på Facebook ved at udstille dig selv og dine private detaljer.

Selvom heltinden i Ridley Scotts reklamefilm heroisk splintrede Store Broders teleskærm og dermed forhindrede, at 1984 blev til 1984, så opstod der en ny overvågningskultur af splinterne: En interfacekultur, som først manifesterede sig i en

5 Cf. Christian Ulrik Andersen, “Interfacet Som Våben, Værktøj Og Legetøj - Sage, Nls, Spacewar! Og 60’ernes Digitale Kultur," Interface - Digital Kunst $๘$ Kultur, eds. Lone Koefoed Hansen and Søren Pold (Aarhus: Aarhus Universitetsforlag, 2007). Denne genfortolkning er selvfølgelig langt mere end blot en retorisk øvelse eller et reklamestunt, men bygger på uomgængelig tænkning, design og udvikling frem mod vore dages computer og internet. For en række centrale historiske tekster se f.eks. Ted Nelson, Douglas Englebart, Alan Kay \& Adele Goldberg i Noah Wardrip-Fruin and Nick Montfort, The New Media Reader (Cambridge, Mass.: MIT Press, 2003). 
venlig Macintosh og lidt senere i en knap så charmerende Windows PC på vores skrivebord. Efterhånden blev denne kultur mere social og kommunikativ i og med, at pc'erne blev forbundet til internettet og senest Web 2.0s sociale kommunikationsplatforme. ${ }^{6}$

Det er dette 1984, som Macintoshen, PC'en og ikke mindst nettet har skabt: En interfacekultur, som langt fra kun påvirker vores arbejde, men i stadig højere grad også vores fritid, kultur, privatsfære, hjem etc. En kultur, hvor vi indretter os efter interfacet for at kunne se os selv i dets skærmbillede. Interfacet er blevet et kulturelt medium - et medium, vi erkender og interagerer med virkeligheden gennem og samtidig bruger i vores egen selvfremstilling, hvilket ikke mindst web 2.0 tjenester som Facebook er et godt eksempel på.

Computerens interface kan altså betragtes som en teknologisk og kulturel form, der korrigerer vores opfattelse af overvågning og sætter overvågningen ind i en kontekst, hvor vi selv delvist kan bruge den, spille med den, udtrykke os ved hjælp af den. ${ }^{7}$ Overvågningen er altså ikke kun noget, der foregår usynligt bag skærmen, som i citatet fra 1984, men noget, der integreres i interfacets udtryk. ${ }^{8}$ Samtidig står vi nu på tærsklen til en ny fase i udviklingen af interfacet, hvor det også indtager rummet, byen og dermed endnu mere af vores livsverden.

Hurtigt skitseret kan man dele interfacehistorien op i en række faser: Interfacets rødder ligger i tekniske betjeningspaneler og switches, hvormed de første computere blev betjent, men efterhånden udvikledes tekstlige interfaces som kommandolinjeinterfacet kendt fra DOS og UNIX. Macintoshens 1984 markerer den fase, hvor det grafiske interface kommer ud af laboratoriet og bliver en uadskillelig del af pc'en. Med WWW og specielt web 2.0 bliver interfacet socialt, og vi står nu på tærsklen til det, jeg vil kalde det urbane interface, hvor byens rum, byoplevelsen, interaktionen $i$ byen bliver medieret af interfaces. Vi er ved at vænne os til bærbare pc'er, tablets og smartphones med kameraer, medieafspillere, GPS-enheder etc., og disse mobile enheder kobles i stigende grad sammen med det sociale interface via web 2.0 tek-

6 Man kan jo altid diskutere, hvornår en interfacekultur indledes - her vælger jeg den kommercielle og populære introduktion af det grafiske bruger-interface som startpunkt, altså Macintoshen. PC'en er ældre, men de første år indtil Windows med et kommandolinje-interface. Se endvidere Steven Johnson, Interface Culture: How New Technology Transforms the Way We Create and Communicate, 1st ed. (San Francisco: HarperEdge, 1997). og Lev Manovich, The Language of New Media (Cambridge, Mass: MIT Press, 2001). for interfacekultur og det kulturelle interface.

7 Det er klart, at fokusset på terror siden 11. september også har været en kraftig faktor i forhold til at påvirke vores accept af overvågning, men i dette tilfælde uden på samme gennemgribende måde at genfortolke overvågningens betydning.

8 Samtidig er der selvfølgelig stadig masser af skjult overvågning bag skærmen, som sikkert udføres af efterretningstjenester, virksomheder, hackere og andre aktører. Mange af de nye sociale nettjenester kan f.eks. betragtes som skalkeskjul for en ny form for fremskudt direkte markedsføring, og der er vedholdende spekulationer om, hvordan Google, Yahoo, Microsoft, Facebook m.fl. bruger alle de oplysninger, de samler om os - hvorvidt de f.eks. udleverer dem til amerikanske sikkerhedstjenester eller til mere eller mindre totalitære regimer, hvor de ønsker at gøre forretning. For en meget kritisk vurdering af Facebooks overvågning og relationer til neo-konservative og evt. CIA, se Tom Hodgkinson: "With friends like these...", The Guardian, 14 January 2008, 〈http://www.guardian.co.uk/technology/2008/jan/14/facebook> (besøgt 02.08.2010). 
nologier og platforme, som giver brugeren adgang til stedsspecifikke oplysninger, men også annoncører og softwarefirmaer som Apple og Google adgang til detaljeret GPS-baseret overvågning af brugeren. ${ }^{9}$ Medieforskeren Lev Manovich har beskrevet denne "augmentering", dvs. forstærkning af rummet som bestående af to teknologier: overvågning (surveillance), som henter rummet og dets aktører ind i computeren, og mobile netværk ("cell space"), som bringer computeren og dens data ud i rummet. Terminalerne, som dette interface sammensættes ved, er både små mobile interfaces (mobiltelefoner, bærbare, pda, ipods...) og store urbane interfaces og andre former for rumlige interfaces (mediefacader, mediearkitektur etc.). ${ }^{10}$

Dette urbane interface - med dets mange terminaler og bestanddele - er allerede en væsentlig del af vores byrum; tænk blot på, hvordan folk mødes via sms og i stigende grad GPS-baserede sociale tjenester som f.eks. Foursquare og tager deres arbejde med på café med deres bærbare eller tablet pc'er. ${ }^{11}$ Samtidig er der et kulturelt og teknologisk begær efter at udnytte og udvikle det urbane interface f.eks. gennem de mange aktuelle sammenkoblinger mellem det urbane rum og web 2.0-platforme som f.eks. Google Earth/Maps samt virtuelt organiserede og dokumenterede happenings i det urbane rum inden for street art, flash mobs, etc. Dette begær efter at blive del af det urbane sociale interface bliver i stigende grad til en måde at 'være på' og en måde at vere på. Vi logger frivilligt ind i overvågningskredsløbet, når vi tænder for vores GPS-smartphone, stiller personlige data mere eller mindre uhindret til rådighed, opdaterer vores Facebook og Foursquare. Set fra 1980'ernes totalitære DDR kan det synes uforklarligt, som om vi alle er blevet konsekvensløse og ureflekterede narcissistiske voyeurer uden kritisk bevidsthed. Eller er det blot en ny måde at være social på? En måde at erkende det sociale urbane interface, at finde ud af, hvad det er, at afprøve dets æstetiske muligheder, måske endda at hacke det?

\section{Overvågning i byen}

En række kunstneriske værker og happenings har arbejdet med overvågningsteknologi i det urbane rum, ofte som en måde at undersøge og samtidig gøre opmærksom på overvågningen. En særlig kunstform har udviklet sig omkring udnyttelsen og udforskningen af eksisterende overvågningskameraer, der jo er en form for overvågning, vi ser overalt, og som har været en del af bybilledet de seneste årtier, ikke

9 På Apples iPhone kan man selv styre om de enkelte applikationer skal have adgang til GPS-data, men man kan ikke slå Apples adgang til indsamling af GPS-baseret information fra, da den er del af deres forretningskoncept. Det forholder sig tilsvarende med smartphones baseret på Googles operativsystem Android. Se f.eks. Jacob Ø.Wittorff: "Nu indsamler Apple alle dine geografiske data - Klikker du "ja” til Apples nye licensbetingelser, får virksomheden mulighed for at overvåge din færden.”, Computerworld, 23.juni, 2010, < http://www. computerworld.dk/art/56696> (besøgt 02.08.2010).

10 Manovich "The poetics of urban media surfaces".

11 Foursquare er lokationsbaseret social netværkssoftware, der samtidig fungerer som et spil, hvor man tjekker ind, kan se, hvor ens 'venner' har tjekket ind, kan efterlade beskeder og vinde emblemer og f.eks. blive et steds borgmester (<http://foursquare.com/〉 (besøgt 02.08.2010)). Der findes flere alternativer f.eks. Brightkite, Gowalla, Google Latitude, etc. Den mest hypede tablet PC er pt. Apples iPad, men alternativer er på vej. 
mindst siden 11. september 2001 med den stigende fokusering på terror. Som en af de første kunstnergrupper har Surveillance Camera Players opført stykker for overvågningskameraer i adskillige byer, bl.a. Orwells 1984, som blev opført på 14th St. and 7th Ave subway station i New York, 3. og 9. november $1998 .{ }^{12}$ Hvor Surveillance Camera Players ikke havde direkte adgang til billederne fra overvågningskameraerne, men måtte nøjes med at se og filme de opsatte skærme, er der flere grupper, der aktuelt arbejder med at få direkte adgang til kameraernes billeder. Det britiske Me-

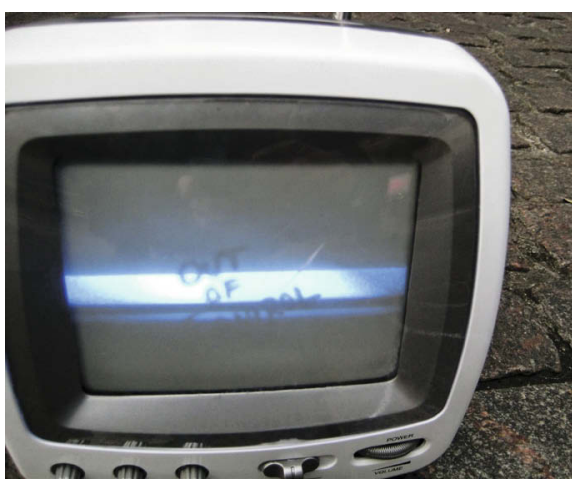

Figur 1: Space Hijackers og Leipziger Kamera hacker overvågningskamera i Århus, foto: Lars Bo Løfgreen diashed lavede i marts 2007 en film i et indkøbscenter i Manchester, hvor de optog en duel mellem to såkaldte "free running", parkour-løbere via indkøbscentrets eget netværk af 160 overvågningskameraer. Resultatet er en flot koreografi, som viser de to duellanter gå akrobatisk amok på gelændere, trapper, etager etc., samtidig med at man forbløffes over den detaljerede kameraopsætning, der trods de undertiden lidt specielle vinkler, ikke lader andre moderne kamerakoreografier meget efter. Ved denne lejlighed fik Mediashed adgang til kameraerne gennem indkøbscentret, men senere har de arbejdet med at få uautoriseret adgang til overvågningskameraer. Mange kameraer sender i dag deres signal trådløst til en server, og det er lykkedes Mediashed-projektet Video Sniffin’ at få adgang til disse trådløse signaler, således at kameraernes signal kan bruges til at lave film (<http://mediashed.org/duellists $>$ og 〈http://mediashed.org/videosniffincom> (besøgt 02.08.2010)). Space Hijackers og Leipziger Kamera arbejder også med trådløse kameraer, og under Sousveillance konferencen i Aarhus lykkedes det dem både at opsnappe billeder fra et trådløst overvågningskamera, men også at transmittere billeder fra et andet kamera, der viste et out-of-control skilt, til overvågningskameraet.

Desuden iværksatte de performances med at bryde maskeringsforbuddet. Den estiske kunstner Mare Tralla optrådte i en selvovervågningsdragt, hvor en række webkameraer overvåger hendes egen krop, og desuden malede hun billeder af udvalgte overvågningskameraer, hvilket skabte opmærksomhed og debat mellem kunstneren og de folk, der kom forbi og undrede sig over motivet.

12 Jf. <http://www.notbored.org/scp-performances.html $>$. På dette website beskrives opførelsen d. 9. november. Der ligger videodokumentation af opførelsen d. 9. november 1998 på YouTube, bl.a. på <http://www.youtube. com/watch?v=9icNuBvJyc0>. Her hører og ser man også, hvordan politiet ankommer og forgæves forsøger at finde ud af, hvad der foregår. Videodokumentationen består af en håndholdt filmning af en monitor ved indgangen til subway'en, som viser billeder fra overvågningskameraet. 


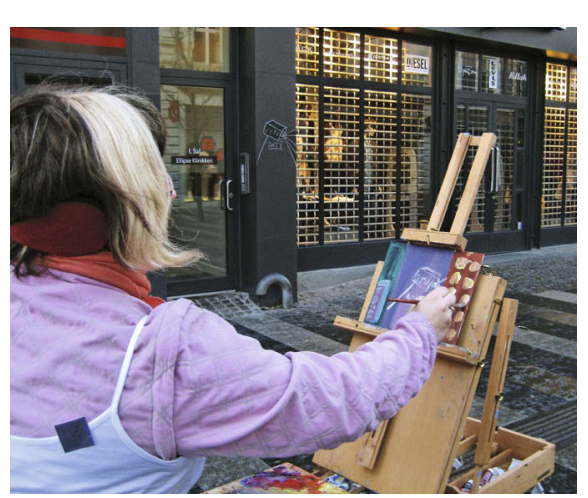

Figur 2: Mare Tralla maler et billede af en kridttegning, som markerer det sted, hvor Space Hijackers og Leipziger Kamera hackede overvågningskameraet, foto: Lone Koefoed Hansen.

Et af de mest gennemførte filmiske eksperimenter med overvågningskameraer er Manu Luksch' 50 minutter lange spillefilm Faceless (Luksch). ${ }^{13}$

Faceless er optaget i London, som har den højeste tæthed af overvågningskameraer i verden, og det estimeres, at man på en gennemsnitlig dag i London vil blive filmet 300 gange (McCahill and Norris, 6). Luksch har ikke haft direkte adgang til overvågningskameraerne som i Mediasheds Video Sniffin', men har i stedet fundet en juridisk udvej, som er med til at skabe filmens rammer på forskellige måder. Data Protection Act 1998 er en britisk implementering af et EU direktiv, der giver en person ret til at købe kopier af data (for maksimalt $£ 10$ ), hvor hun selv indgår, hvis en række regler er opfyldt: Det skal være personlige data (det vil sige, hun skal være på filmen), det skal være en større operatør med flere kameraer, og alle andre aktører skal gøres uidentificerbare for at hemmeligholde deres identitet. Derfor har alle andre personer i filmen pletter oven på ansigterne eller er gjort uigenkendelige ved, at ansigterne er klippet ud. Disse betingelser har Luksch omsat til et "Manifesto for CCTV Filmmakers”. Her omsættes de særlige omstændigheder til et kreativt manifest, hvor det kræves, at filmskaberen skal "overveje de visuelle effekter af denne manipulation og etablere en regel for håndteringen af materiale, som er leveret uden effektiv maskering eller sløring." 14

Hovedreglen er, at optagelserne skal være autentiske, og der må ikke anvendes yderligere kameraer eller lyssætning, så Faceless er lavet udelukkende via overvågningskameraer med optagelser skaffet gennem Data Protection Act. Som Luksch og skaberen af filmens soundtrack selv udtrykker det: "Kunst bruges til at udforske loven” (Luksch and Patel 73). Luksch fortæller selv, hvordan filmen udviklede sig over årene:

"Der var intet traditionelt manuskript, plottet udviklede sig hele tiden under den fire år lange proces med at få fat i billederne. Scener blev planlagt på bestemte steder, men billederne fra overvågningskameraerne kunne ikke altid skaffes, så fortællin-

13 Filmen kan købes på DVD fra 〈http://www.ambienttv.net/content/?q=faceless>, hvor man også kan se traileren og læse diverse information om filmen. På YouTube kan man også se udsnit fra en tidligere installations-version af materialet bag Faceless (Faceless - The Spectral Children, 2006), <http://www.youtube.com/ watch?v=RW2ZLGQli00> (besøgt 02.08.2010).

14 Manifestet er tilgængeligt her: 〈http://www.ambienttv.net/content/?q=dpamanifesto〉, hvor der også henvises til de relevante lovtekster. 


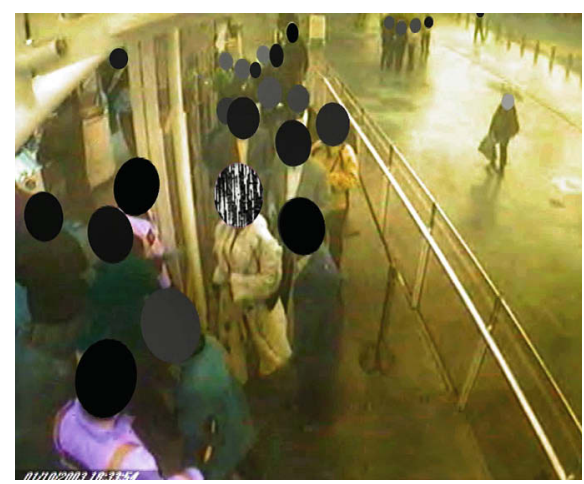

Figur 3: Manu Luksch' Faceless

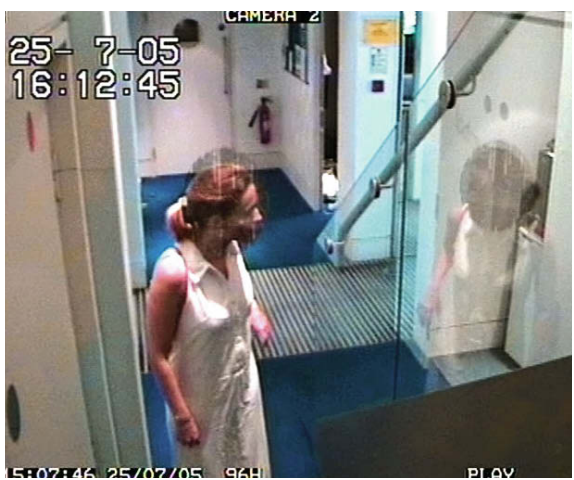

Figur 4: Faceless, Scenen hvor kvinden får sit ansigt igen.

gen måtte hele tiden genskrives. Faceless bruger overvågningskamerabilleder som juridiske readymades/objet trouve. "15

Filmen udviklede sig altså i en vekselvirkning mellem planlægning og de resultater, der kom ud af det. På trods af Data Protection Acts rettigheder, så er der mange kameraoperatører, der på forskellige måder vægrer sig ved at udlevere materialet formodentlig bl.a. på grund af udgifterne til at anonymisere øvrige personer på filmen - og Luksch fortæller også om en lang række tilfælde, hvor det viste sig, at kameraerne ikke virkede og oven i købet aldrig havde virket. ${ }^{16}$

Faceless handler om en kvinde (nødvendigvis spillet af Manu Luksch selv), som lever i en fremtidig dystopisk teknologisk tidsalder, hvor "The New Machine" styrer og organiserer tiden således, at den ikke er kontinuerligt fremadskridende, men forløber i pulserende øjeblikke, den såkaldte "RealTime". Denne maskinelle tidsstyring styrer alle borgeres liv og gennemsyrer deres bevidsthed i en grad, så det udelukker både erindring og fremtidsforventning og dermed også skyld, fortrydelse og fremtidsangst og frygt: "RealTime, den perfekte og vedvarende nutid, er hjerteslaget i det sunde univers" (Luksch), som filmens fortæller opsummerer det. ${ }^{17}$ Desuden overvåger The New Machine byen og monitorerer beboernes dataspor i et perfekt Store Broder system, hvor den oven i købet kan sende "Overseers" for øjeblikkeligt at korrigere alle fejl og afvigelser. Men kvinden, som er ansat som en af de mange tusinde, der analyserer The New Machines data, er "hjemsøgt af ekkoer

15 "There was no traditional shooting script: the plot evolved during the four-year long process of obtaining images. Scenes were planned in particular locations, but the CCTV recordings were not always obtainable, so the story had to be continually rewritten. Faceless treats the CCTV image as an example of a legal readymade (objet touve)." (Luksch and Patel, 74).

16 Jf. (Luksch and Patel 74 ff.) og Luksch' egne foredrag om filmen, Transmediale 2008 i Berlin, og Sousveillance 2009 i Aarhus).

17 Filmens voice-over fortæller er den anerkendte britiske skuespiller Tilda Swinton, og manuskriptet kan findes på filmens website: 〈http://www.ambienttv.net/content/pdf/faceless_voiceover.pdf〉. 
af en erindring" (Luksch). Hun modtager et brev, der opfordrer hende til at følge sine drømme, og hun forfølger dem på tværs af byen. I en scene får hun sit ansigt igen, hvorefter hun jages af "Overseers" men møder nogle farverige "spektrale børn”, markeret af farvede klatter på hovedet, som er frigjort fra The New Machine.

Senere møder hun sin tidligere elsker, som er brevets afsender og forklarer hende sagernes sammenhæng. Han har i mellem tiden arbejdet som "Overseer", men tilbyder at smugle hende med en "Seapod" over "The Blue Wa-

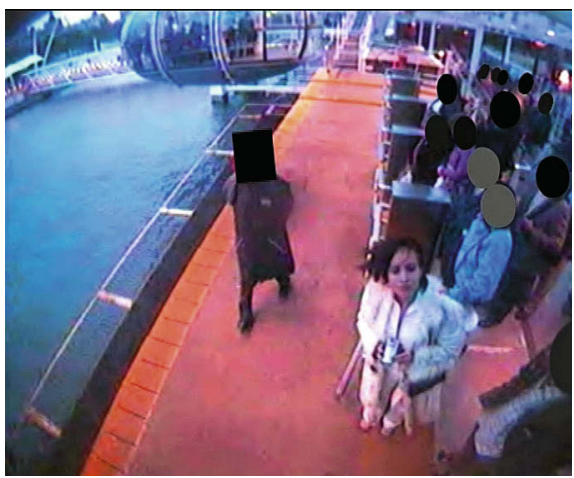

Figur 5: Faceless, ved 'Seapod'en som Londonrejsende vil kunne genkende som “London Eye" pariserhjulet ter", hvor hun kan infiltrere The New Machine for at befri byen.

Det lykkes hende, og hun bliver forenet med sin fortid og fremtid, elsker og deres fælles barn. Filmens fortæller slutter dog med at drage befrielsen i tvivl:

"Hendes barn? Hendes elsker? Tvivlen voksede. Er dette hendes drøm, hendes fortid? Eller nostalgi efter en tid, der aldrig har eksisteret? Et fængsel for en anden perfekt nutid?" (Luksch).

Filmens fortælling følger således et klassisk Store Broder skema, hvor protagonisten heroisk befrier sig selv og sin by gennem en "kærlighed, som gennemtrænger RealTime” (Luksch). Langt hen ad vejen en overvågningskritik i traditionen fra 1984, og som den f.eks. også ses i The Matrix, trods ambivalensen mod slutningen om, hvorvidt man overhovedet kan befries, og om befrielsen er ægte. Filmen er gennem sin fortælling på mange måder en kritik af en tid parallelt med vores, hvor vi installerer overvågning og kontrol pga. angst for fremtiden og skyld over fortiden og hvor tilfredsheden trods frihedstabet er udbredt. ${ }^{18}$ På denne måde udtrykker filmens fortælling en kritik af overvågningen og de mekanismer, der sætter den i værk, men filmens overvågningsbilleder rummer mere end denne velkendte kritik.

Filmen rummer - også i kraft af Mukul Patels surround-soundtrack med bl.a. Robert Hubers klavermusik - en skønhed, undertiden med undertoner af melankoli

18 Luksch og Patel slutter deres essay med at overveje effekten af - og den fortsat høje tiltro til overvågning, eftersom det har vist sig, at overvågning ikke er så effektivt som antaget, og Luksch har jo med sine forsøg på at indhente optagelser også afdækket store huller i panoptikonet: "Panoptikonet er ikke fuldstændigt, endnu. Vil dets envejsblik mon overhovedet nogensinde kunne give os en tilstrækkelig grad af sikkerhed?" ("The panopticon is not complete, yet. Regardless, could its one-way gaze ever assure an enabling conception of security?”) Manu Luksch and Mukul Patel, "Faceless: Chasing the Data Shadow," Goodbye Privacy - Ars Electronica 2007, eds. Gerfried Stocker and Christine Schöpf (Ostfildern: Hatje Cantz, 2007) 78. 
fra klaveret. Andre gange er skønheden mere teknologisk og glitsch-præget, i særlig grad sekvensen, hvor overvågningskameraernes panoptikon bryder sammen (45.20 ff.), men på mere subtil vis præger det også filmen generelt.

I sagens natur er filmen præget af overvågningskameraernes æstetik (f.eks. uskarphed, skidt på linsen, flimren, overbelyste og -mættede farver), deres indstillinger (ofte mere eller mindre tilfældige fugleperspektiver og tilfældigt komponerede billeder) samt kameraernes immobilitet. Det giver filmen en

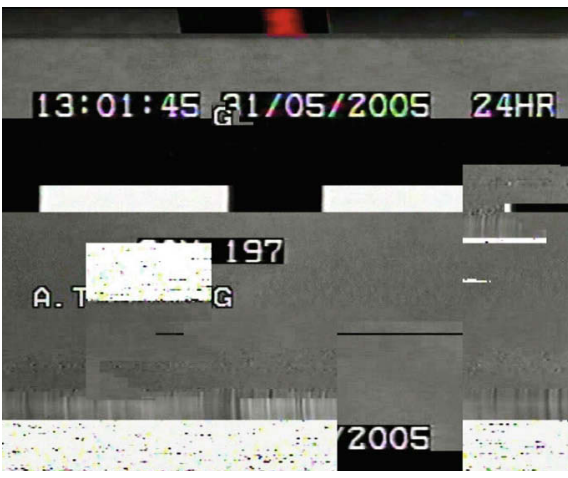

Figur 6: Faceless, billedstøj fra fejlende kameraer særlig dehumaniseret og 'objektiv' kvalitet, at dens kameraer ikke er betjent af menneskehånd, hvilket også har betydning for tid og perspektiv:

Tiden går ofte i ryk af et billede pr. sekund i stedet for de sædvanlige 25 billeder pr. sekund, hvilket understøttes af musikkens sekund-slag, og af billedernes altid synlige tidskode fra overvågningskameraerne. Manu Luksch fortæller selv, at fortællingen om The New Machines' pulserende øjeblikke af RealTime blev udviklet som reaktion på prøvevisninger, hvor hun iagttog, at publikum var meget fokuserede på overvågningsbilledernes tidskoder. Fortællingen er dermed også her, som i hovedtemaet om de ansigtsløse, en direkte følge af billedernes karakter. Samtidig er tiden nogle gange speedet op og viser dermed udviklinger og processer, vi normalt ikke ænser - skyggers og tidevands passage som i en smuk scene ved en kanal (21.40 ff), hvor over tre timer er kondenseret til få minutter.

Andre steder står tiden stille eller går i loops over en periode. Tiden bliver altså generelt til noget, der er manipulerbart, og som kontrolleres af de maskinelle magter, der kontrollerer byens beboere. Tiden er således fuldstændig fjernet fra det levede livs erfaring med dets linearitet, varighed og narrative erfaringsopbygning til fordel for en maskinel måde at kontrollere og umyndiggøre individerne. Tiden giver ikke sammenhænge, mening og fører ikke til forståelse for den enkelte, men kontrolleres maskinelt og vilkårligt.

Perspektivet er bemærkelsesværdigt. Manu Luksch hæfter sig selv ved, at overvågningskameraer stort set altid ser fra et fugleperspektiv for at skabe overblik og fange mest muligt ind. Det er et kameraperspektiv, som er langt fra det subjektive kamera, vi er vant til i film - i stedet for at portrættere individer ser det masseoptog - eller med Siegfried Kracauer "masseornamenter”. Kracauer skrev i 1927 med udgangspunkt i bl.a. store stadion-danseshows om masseornamenter og deres betydning i moderniteten. Masseornamentet er i Kracauers forståelse en æstetisk refleksion over den kapitalistiske produktionsproces, samlebåndet, massesamfundet og den statistiske kontrol. Alt sammen ting, som er uerkendelige for den enkelte på andre måder end som indirekte erfaring og igennem æstetisk iscenesættelse af masseornamenter: 


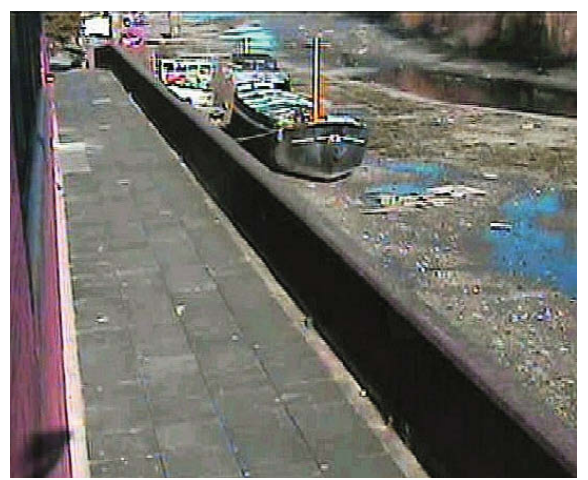

Figur 7: Faceless, scenen ved kanalen

"Den enkelte tager vare på sit område ved samlebåndet, udøver en delfunktion uden at kende helheden. Som ved det mønster, der tegner sig på stadion, står organisationen over massen, en monstrøs figur, som af ophavsmanden unddrages bærerens synsfelt, og som dårligt nok har bæreren som betragter." (Kracauer 336).

På denne måde erkendes massesamfundet gennem masseornamentet. Samtidig sker der igennem den ornamentale iscenesættelse en fortryllelse af det kapitalistiske massesamfund - det opleves som et samlet projekt: "Ornamentets bærer er massen, ikke folket" (Kracauer 334) og heller ikke det personlige individ. En fortryllelse, fascismen og nazismen udnyttede eller måske snarere misbrugte og perverterede, ikke mindst i Leni Riefenstahls iscenesættelse. ${ }^{19}$ Overvågningskameraerne viser dermed et visuelt masseperspektiv parallelt med det abstrakte, informationelle masseperspektiv, der konstrueres af den data-mining, som hovedpersonen beskæftiger sig med, når hun inspicerer dataspor indsamlet fra den nye maskine. Overvågningskameraernes billeder i filmen er automatiske og interesseløse billeder af anonymiserede, ansigtsløse masser. Filmen skaber en konstellation af et overvåget rum, der bærer mange paralleller til den måde, en londoner vil kunne følge hele sin dags færden på video, hvis han kunne få adgang til de gennemsnitligt 300 kameraer, der har fanget hans færden. Det er således denne proces med at skaffe sig adgang, som Manu Luksch har gennemført, og hun har dermed i sin film demonstreret en form for altseende overvågningssystem, der anlægger et masseperspektiv.

Hvor Kracauer tog udgangspunkt i danseshows, har Luksch selv henvist til den toneangivende musical-instruktør og koreograf fra 1930'erne, Busby Berkeley, som filmede danseoptog med et panoptisk perspektiv, således at specielt mønstrene i dansen trådte frem, og de dansende blev til en ny større super-organisme - som myrer i en myretue eller elementer i en (samfunds-)maskine. Som del af materialet i Faceless indgår The Eye - Choreography for surveilled space (med George Piper Dances/ The Ballet Boyz, Lakeside Shopping Centre, 2005), som er en koreografi med 80 performere optaget fra indkøbscentrets overvågningskameraer og Luksch fremstiller det selv som en kalejdoskopisk humoristisk hyldest til Busby Berkeleys Hollywood musicals. ${ }^{20}$ I koreografien er det tydeligt, hvordan de overvågede bliver til mønstre skærpet af de her farvede ansigtsafdækninger. 
Men også i de mindre koreograferede og mere tilfældige scener demonstrerer filmen et mønster-agtigt perspektiv - en måde at se mennesker på, som netop kun det dehumaniserede og automatiserede kamera kan vise, fordi der netop ikke er nogen intention bag billederne.

Det er dette overvågningsperspektiv og denne maskinelle tidskontrol, som udgør filmens dystopiske, kritiske stemme, men den rummer mere end det: En særlig skønhed, som måske ligger i filmens fortællings modstand mod

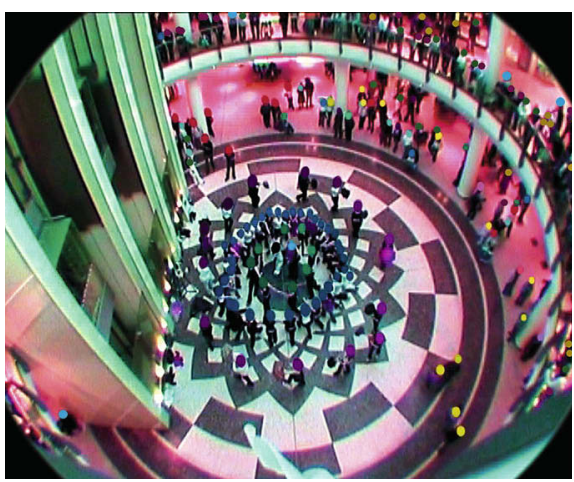

Figur 8: Faceless, The Eye koreografien overvågningsparadigmet, men for mig at se snarere konstrueres af filmens visuelle æstetik. En æstetik, som tager sit tydelige udgangspunkt i materialet; måden, dens materiale er indsamlet og opbygget som "juridisk ready-made" og dermed peger på et reelt eksisterende overvågningssamfund. Dette udbygges i den måde, filmen genbruger materialet på, hvilket kan ses som en form for kunstnerisk modstand, der peger på de kunstnerisk-æstetiske muligheder for at udtrykke sig i dette overvågningssamfund, som en delvis transcendering af det. Endelig ligger den særlige æstetiske kvalitet i billederne selv; hvad der kommer til syne i konstellationen af dem: Overvågningskamera-billederne kan karakteriseres med Walter Benjamins begreb om det optisk ubevidste, der på en gang medvirker til, demonstrerer og potentielt sprænger modernitetens panoptiske, bureaukratiske og kapitalistiske fængsel:

"Idet filmen gennem nærbilleder af dens inventarium, gennem fremhævelse af skjulte detaljer ved de for os velkendte rekvisitter, gennem udforskning af banale miljøer under objektivets geniale ledelse, på den ene side forøger indsigten i de tvangsmæssigheder, som vores eksistens styres af, kommer den på den anden side til at love os et uhyre og uanet spillerum! Vi syntes at være håbløst lukket inde i vore beværtninger og storbygader, vore kontorer og møblerede værelser, vore banegårde og fabrikker. Da kom filmen, og den har med tiendedelssekundernes dynamit sprængt denne fængselsverden, så vi nu afslappet foretager eventyrlige rejser mellem dens vidtspredte ruinhobe. I nærbilledet breder rummet sig ud, i slow-motion gør bevægelsen det. Og så lidt som det i nærbilledet drejer sig om blot at tydeliggøre det, som man 'i forvejen' ser utydeligt, men snarere om, at fuldstændig nye strukturdannelser i materien kommer til syne, lige så lidt bringer slow-motion blot kendte bevægelsesmotiver til syne, men derimod afslører den i disse kendte nogle helt ukendte, 'som virker slet ikke som hurtige bevægelser, der bliver sagtnet, men som ejendommeligt glidende, svævende, overjordiske bevægelser.' På denne måde bliver det håndgribeligt, at det er en anden natur, som taler til kameraet end til øjet.” (Benjamin 151-52, med citat af Arnheim). 
Kameraet viser potentielt gennem sit optisk ubevidste et sådant rum hinsides det humane perspektiv, hvor skuespillerne bliver til rekvisitter, mens rekvisitterne, rummet og kulisserne bliver fortællende - vi kender delvist æstetikken fra noir-film og gotiske gys, hvor man ofte kan forudse, hvad der vil ske ud fra kulissernes karakter, men her er der i modsætning til sådanne film ikke tale om iscenesættelse. I Faceless er skuespillerne (på nær Manu Luksch selv samt de koreograferede og iscenesatte karakterer) tilfældige tilstedeværende, anonymiserede og således på niveau med kulisserne, men samtidig får man øje for et større perspektiv. Rummet i filmen er således både panoptisk sammenhængende, gennemscannet, kontrolleret og samtidig heterogent, sprængt som den pulserende RealTime, og opløst i nye mønstre og strukturer.

Faceless' æstetik er altså præget af overvågningsperspektivets dehumaniserede perspektiv, af maskinens perspektiv. Både dens fortælling, manifest, tid, rum og visuelle æstetik er nødvendiggjort af materialets karakter af ready made, af fundet materiale, som derved har en særlig objektiv karakter, som ikke har kunnet kontrolleres fuldt ud af kunstneren. Perspektiv, rum, tid og fortælling er ikke fuldt ud styret af Manu Luksch, men nødvendiggøres af materialet. Filmen vokser ud af vilkårene, reglerne og juraen. Derfor kan den ikke undgå at være en film om overvågning - men også en film, der demonstrerer overvågningens perspektiv, som fortælling og visuel æstetik. Den viser en dimension af, hvordan overvågningen også kan transformeres til at skabe sammenhænge, fortælling, skønhed, urbanitet og steder. En koreografi for det overvågede rum: "Cirkler hvirvler inden i cirkler, drømme inden i drømme. Kort, koder, ritualer - dansen synger om mange ting, som er ukendte for hende.” $(23.50)$

\section{Interfacebegcer}

Faceless tematiserer, hvordan det urbane rum er blevet overvåget og registreres i databaser. Det overvågede menneske har i udgangspunktet ingen muligheder for interaktion. Filmen viser alligevel - og i forlængelse af projekter som Surveillance Camera Players og Video Sniffin' - hvordan man kan tilegne sig og udtrykke sig via de allerede implementerede overvågningsteknologier. Andre kunstprojekter som f.eks. Raphael Lozano-Hemmers Relational Architecture ${ }^{21}$ viser, hvordan overvågningsteknologier kan monteres i interaktive byrumsinstallationer og skabe mødesteder mellem passerende mennesker, specifikke steder, arkitektur og teknologi. Fokus er her på at give folk mulighed for at udtrykke sig med teknologien - at indtage det urbane interface, samtidig med at teknologien demonstreres og dermed også på sin vis afsløres. Her er al teknologien dog knyttet direkte til kunstværket, og værkerne rummer ikke samme kritiske kommentar til den teknologi, der allerede forefindes og er i brug i byrummet. Kritikken peger måske snarere på, hvordan teknologien potentielt kan udvikles. 
Sådanne værker demonstrerer et begær efter at tage del i og samtidig erkende masseornamentet, hvilket for Kracauer var umuligt og derfor netop blev iscenesat æstetisk. Siden Kracauer skrev sit essay i 1927 er massesamfundet i stigende grad blevet teknologisk understøttet, ikke mindst via computere og netværk som internettet. Samtidig er det blevet stadig mere differentieret og komplekst - og dermed også sværere at få øje på. Det urbane interface er endnu sjældent så håndgribeligt som i Lozano-Hemmers værker - ofte er det skjult og ikke umiddelbart til at interagere med uden kunstneriske greb som hos overvågningskunstnerne. Måske er fænomener som Flashmobs - hvor hundreder af personer pludselig stopper op og fryser midt på en travl banegård for kort efter at bevæge sig videre igen, som om intet var hændt - et aktuelt masseornament eller urbant interface i sin uudgrundelige demonstration af, hvordan virtuelle netværk effektivt og fleksibelt manifesterer sig i det fysiske rum?22

Et andet eksempel på en legende og lettere absurd kunstnerisk strategi, der synliggør urbane interfaces og fører web 2.0s socialitet ud i byrummets fysiske virkelighed, er Aram Bartholls Datenform-projekter. I disse projekter udforsker han gennem forskellige værker og interventioner - gerne af meget simpel og papkasseagtig karakter - sammenhænge og forskelle mellem vores sociale interfaces og rum. Han tager elementerne fra web 2.0 interfaces og bygger dem i pap, ståltråd etc. i en række gør-det-selv workshops, hvor publikum inddrages, og fører dem derigennem ud i det fysiske rum. På denne måde gør han humoristisk og tankevækkende opmærksom på forskelle og ligheder og iscenesætter en legende sammenligning af de to rum. ${ }^{23}$

Bartholls værker handler mindre om overvågning, men i høj grad om begæret efter at blive del af interfacet, del af mønstret - at blive synlig på et mere abstrakt og generaliseret niveau. Som eksemplerne viser, har overvågningen en æstetik, en kultur, som ikke kun handler om terrorfrygt, men også om synlighed og synliggørelse i de urbane interfaces. Overvågningen og de urbane sociale interfaces er en ny scene at spille på - et nyt interface at interagere med. Overvågningens tillokkelse er også en måde at ane de usynlige, abstrakte strukturer, der udgør byen og samfundsmaskineriet, og som vi hver især kun udgør en lille delfunktion af uden at kunne erkende helheden (jf. Kracauer). Overvågningens billeder - i det omfang vi får dem at se som i disse og mange andre kunstprojekter - rummer en sublim social dimension. Den anes i de uskarpe billeder og det dehumaniserede perspektiv, uden nogensinde at komme fuldt til syne som andet end en dystopisk konspiration eller en patetisk drøm.

22 Om projektet Frozen Grand Central se <http://improveverywhere.com/2008/01/31/frozen-grand-central/> Se også bloggen 〈http://urbanprankster.com/> (besøgt 02.08.2010).

23 Se <http://www.datenform.de/> (besøgt 02.08.2010) f.eks. Follow Me, Computer Game Objects, Second City, Chat, Missing Image, First Person Shooter, WoW m.fl. Bartholl optræder hyppigt på mediekunstfestivalerne f.eks. på Transmediale $(2007,2008)$ og Ars Electronica $(2006,2007)$. 
En sidste og ganske vigtig pointe i forhold til Faceless angår alt det, man ikke kan se, som foregår uden for og mellem billederne og måske på de billeder, der er gået tabt på grund af kameraer, som ikke virkede, billeder, der er blevet slettet eller aldrig fundet frem. En væsentlig pointe med Manu Luksch' film er alle dysfunktionaliteterne og den manglende synlighed. Det totale panoptiske overblik findes ikke, og filmens overvågningsfortælling opstår i forskydningen mellem forskellige overvågningskame-

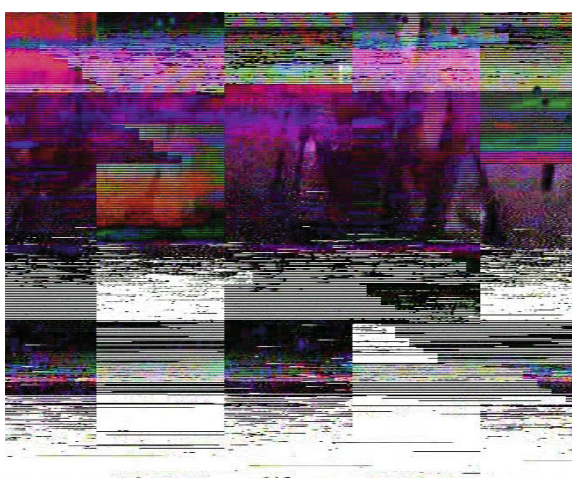

Figur 9: Faceless, billedsammenbrud raers billeder og perspektiver. I sin bog om Paris' forvandling fra Ville Lumière til Ville Invisible skriver Bruno Latour, at panoptikken ikke ser det egentlige, men blot er en utopisk drøm om det altseende perspektiv. I virkeligheden opererer vi altid med blinde vinkler, steds- og kontekstbundne perspektiver og støv på linsen. "Fænomenet viser sig aldrig decideret på billedet, men bliver dog synligt i det, som omdannes, transporteres, deformeres fra et billede til et andet, fra ét synspunkt, fra et perspektiv til et andet". ${ }^{24}$ Faceless viser både fortællingen om usynligheden, det aldrig etablerede altseende blik, og om den fortælling, der alligevel opstår mellem billederne, perspektiverne, kameraerne. Billederne i Faceless er således ikke bare billeder af overvågede subjekter. De er også billeder fra og af en overvågningskultur - et samfund, som er bygget op omkring overvågning, hvor overvågningens dehumaniserede perspektiv er en væsentlig del af det, der holder samfundet sammen. Overvågning er ikke længere noget, vi kan vælge at tænde eller slukke for, den er integreret i samfundets udvikling som en overvågnings- og interfacekultur. Med udgangspunkt i denne indsigt kan vi begynde diskussionen om, hvordan vi forholder os til det, og hvordan det kan gøres på mere hensigtsmæssige måder i fremtiden.

Som disse kunstværker og -projekter demonstrerer, er overvågning i dag meget mere end Orwells totalitære Store Broder-dystopi. Den er en central del af vores interaktive teknologi, vores interaktion med den, vores urbane rum og dermed også af vores kultur. Overvågningen er således ikke kun i totalitarismens tjeneste, om end den stadig tjener vore dages Store Brødre, men kritikken går forbi sit mål, hvis den ikke samtidig har øje for de mange andre dimensioner af, hvordan overvågning virker. Kunsten kan synliggøre overvågningen og dermed potentielt føre den tilbage $\mathrm{i}$ individernes og fællesskabets tjeneste, som noget vi udtrykker os med og gennem. Kunsten kan også få os til at eksperimentere med andre måder at bruge overvågningen på.

24 "Certes, le phénomène n’apparaît jamais sur l'image, mais il devient pourtant visible dans ce qui se transforme, se transporte, se déforme d'une image à l'autre, d'un point de vue, d'une perspective à l'autre." (Latour, Hermant and Shannon 53). 
Overvågning er et vilkår, og måske skal diskussionen ikke kun handle om, hvordan vi beskytter vores efterhånden illusoriske privathed? Måske skal overvågningen i stedet nogle gange synliggøres og åbnes op til fælles brug, så vi bliver bevidste om, hvem og hvad der lurer bag skærmen, og selv kan få lov til at bruge de data, der samles?

Tak til Manu Luksch for at tillade gengivelse af billeder fra Faceless. Denne forskning er udført inden for forskningsprojektet Digital Urban Living finansieret af Det Strategiske Forskningsråd, bevilling nr. 09-063245.

\section{LITTERATURLISTE}

Andersen, Christian Ulrik. "Interfacet som våben, værktøj og legetøj - SAGE, NLS, Spacewar! og 60'ernes digitale kultur." Interface - digital kunst « kultur. Red. Hansen, Lone Koefoed and Søren Pold. Aarhus: Aarhus Universitetsforlag, 2007: 43-80.

Benjamin, Walter. Kulturkritiske essays. København: Samlerens Bogklub, 1998.

Dinesen, Pernille Taagaard, red. Enter action Århus: ARoS - Århus Kunstmuseum, 2009.

Foucault, Michel. Overvågning og straf: fangslets fodsel. Frederiksberg: Det lille Forlag, 2003.

Friedman, Ted. "Apple's 1984: The Introduction of the Macintosh in the Cultural History of Personal Computers." Society for the History of Technology Convention, $\underline{\text { http://www.duke.edu/ } \sim \text { tlove/mac. }}$ $\underline{\text { htm }}$.

Hansen, Lone Koefoed, og Søren Pold, red. Interface - digital kunst ๘ kultur. Aarhus: Aarhus Universitetsforlag, 2007.

Johnson, Steven. Interface culture: how new technology transforms the way we create and communicate. San Francisco: HarperEdge, 1997.

Kracauer, Siegfried. “Massens ornament.” Trans. Rønn, Mette. Visuel kommunikation. Red. Fausing, Bent and Peter Larsen. Kbh.: Medusa, 1980: 331-41.

Latour, Bruno, Emilie Hermant, og Susanna Shannon. Paris ville invisible. Paris: La Découverte, 1998. Luksch, Manu. Faceless. 2007. Amour Four Filmproduktion, Ambient Information Systems, London. Luksch, Manu, og Mukul Patel. "Faceless: Chasing the Data Shadow." Goodbye Privacy - Ars Electronica 2007: Red. Stocker, Gerfried and Christine Schöpf. Ostfildern: Hatje Cantz, 2007: 72-78.

Manovich, Lev. The Language of New Media. Cambridge, Mass: MIT Press, 2001.

- --. "The poetics of urban media surfaces." First Monday Special Issue \#4: Urban Screens: Discovering the potential of outdoor screens for urban society (2006), <http://www.firstmonday.org/issues/ special11_2/manovich/index.html>.

McCahill, Michael, and Clive Norris. "CCTV in London". 2002. (23.05.08): Centre for Criminology and Criminal Justice, University of Hull, UK, 〈http://www.urbaneye.net/results/ue_wp6.pdf>.

Oettermann, Stephan. Das Panorama die Geschichte eines Massenmediums. Frankfurt/Main: Syndikat, 1980.

Orwell, George. 1984. København: Gyldendal, 1984. 
Pold, Søren. "An Aesthetic Criticism of the Media: The Configuration of Art, Media and Politics in Walter Benjamin's Materialistic Aesthetics.” Parallax 12 (1999): 22-36.

- --. Ex libris medierealistisk litteratur, Paris, Los Angeles \& cyberspace. Odense: Syddansk Universitetsforlag, 2004.

Wardrip-Fruin, Noah, and Nick Montfort. The new media reader. Cambridge, Mass.: MIT Press, 2003. 